\title{
Changes in land use in South Africa between 1961 and 2006: an integrated socio-ecological analysis based on the human appropriation of net primary production framework
}

\author{
Maria Niedertscheider • Simone Gingrich • \\ Karl-Heinz Erb
}

Received: 18 May 2011/Accepted: 17 January 2012/Published online: 5 February 2012

(C) The Author(s) 2012. This article is published with open access at Springerlink.com

\begin{abstract}
The interrelation between land-use change and socioeconomic changes is complex and highly dynamic. We here present an assessment of the human appropriation of net primary production (HANPP) in Republic of South Africa (RSA) between 1961 and 2006. HANPP is an integrated socio-ecological accounting framework that traces changes in ecosystems resulting from anthropogenic activities (harvest and land conversions) and allows to study ecological, social and economic driving forces and constraints of long-term land-use changes. We use South Africa, with its history of the rise and collapse of the Apartheid regime, as an example for an analysis of HANPP trajectories in the background of major governance shifts, and base our analysis on the best available statistical datasets, specific analyses and model results. Surprisingly, land cover as well as HANPP in the RSA remained relatively constant between 1961 and 2006, with HANPP values oscillating between 21 and $25 \%$ and of the potential NPP. However, through our analysis of the components of HANPP and their interrelations, striking turning points throughout the last five decades become evident. This allows us to discern three distinct periods, each of the phases characterized by distinct HANPP trajectories. Throughout the entire period, a trend of decoupling of HANPP from population growth could be achieved through
\end{abstract}

Electronic supplementary material The online version of this article (doi:10.1007/s10113-012-0285-6) contains supplementary material, which is available to authorized users.

\footnotetext{
M. Niedertscheider $(\bowtie) \cdot$ S. Gingrich · K.-H. Erb

Institute of Social Ecology,

Alpen-Adria Universitaet,

Schottenfeldgasse 29,

1070 Vienna, Austria

e-mail: maria.niedertscheider@aau.at
}

considerable gains in land-use efficiency. The HANPP analysis reveals that this prevailing trend of increasing land-use efficiency, based on technological improvements and biomass trade, came to a halt in the 'crisis' phase and immediately recovered afterwards.

Keywords HANPP · South Africa - NPP · Land use Biomass extraction - Agricultural change - Biomass flows

\section{Introduction}

Land-use change and socioeconomic change are intrinsically interlinked. By using the land, societies alter ecological structures and processes in order to optimize the provision of goods and services by ecosystems. The resulting changes in ecosystems require adequate social responses, such as altered management schemes, in order to warrant the continuous provision of services and to avoid detrimental ecological effects. This interplay between socioeconomic drivers, pressures, changes in ecological states and impacts is highly dynamic and complex (Liu et al. 2007; Turner et al. 2007; Liverman and Cuesta 2008) and motivated scholars to call for integrated, interdisciplinary perspectives for studying the various aspects of the land system and their change over time (Rindfuss et al. 2004; GLP 2005; Turner et al. 2007).

Empirical information on the complex interactions and feedbacks driving the land system is essential to improve the understanding of trajectories and the underlying mechanisms and constraints of changes in the land system, as well as their relation to sustainable development (Ostrom et al. 2007). As sustainability problems relate to problems of society-nature interactions (Haberl et al. 2004a), accounting systems are required that allow to 
consistently observe, quantify and monitor interactions between societies and their natural environment. Many such indicator systems have been proposed, focussing on the quantification and evaluation of the interplay between socioeconomic management, ecosystem services or the associated social or ecological impacts, for example on biodiversity (see, e.g. Haberl et al. 2004b; GLP 2005; Millennium Ecosystem Assessment 2005; Hák and al 2007).

In this context, the indicator framework Human Appropriation of Net Primary Production (HANPP; Vitousek et al. 1986; Wright 1990; Erb et al. 2007, 2009b; Haberl et al. 2007) received some attention as a biophysical indicator of strong sustainability (MartinezAlier 1998, 1999; Krausmann et al. 2004; Foley et al. 2007; Erb et al. 2009b). HANPP focuses on a key variable of the coupled socio-ecological system: the annual flow of biomass, which is a central parameter for ecosystem functioning (Lindeman 1942) as well as an essential resource of socioeconomic systems, providing the basis of food and feed (Ayres 2007), and representing a key component of the global socioeconomic energy system (Smil 2005).

HANPP quantifies and integrates the effects of two interlinked processes in one account (Fig. 1): (a) Modifications of NPP due to land conversions, for example by converting forested ecosystems into arable land. This component of HANPP is denoted as $\triangle \mathrm{NPP}_{\mathrm{lc}}$ (change in NPP resulting from land conversion) and is calculated as the difference between the NPP of potential vegetation (Tüxen 1956) and the NPP of the currently prevailing vegetation $\left(\mathrm{NPP}_{\mathrm{act}}\right)$. (b) The amount of biomass extracted or destroyed by human activities, for example through biomass harvest or grazing of livestock, denoted as $\mathrm{NPP}_{\mathrm{h}}$. Thus, HANPP is a metric for human-induced changes in the yearly availability of trophic energy in the ecosystems and can be used as an indicator of land-use intensity (Haberl 1997; Haberl et al. 2007). HANPP analyses allow to integrate socioeconomic (harvest of biomass and collateral flows) and ecological perspectives (changes in energy availability in ecosystems) and allow to assess the scope of human action or the scale of the human domination of ecosystems (Vitousek 1997).

However, the concept of HANPP alone is not sufficient for analysing the complex and manifold changes and trajectories in socio-ecological systems, as it only focuses on a limited amount of variables and is centred around the question of 'domestic extraction', that is the domestic use of ecosystems, which does not allow to straightforwardly link land-use changes to for example consumption of biomass products, a major driver of land-use change (Erb et al. 2009a; Krausmann et al. 2009b). Nevertheless, HANPP focuses on a key variable of both ecological and socio-

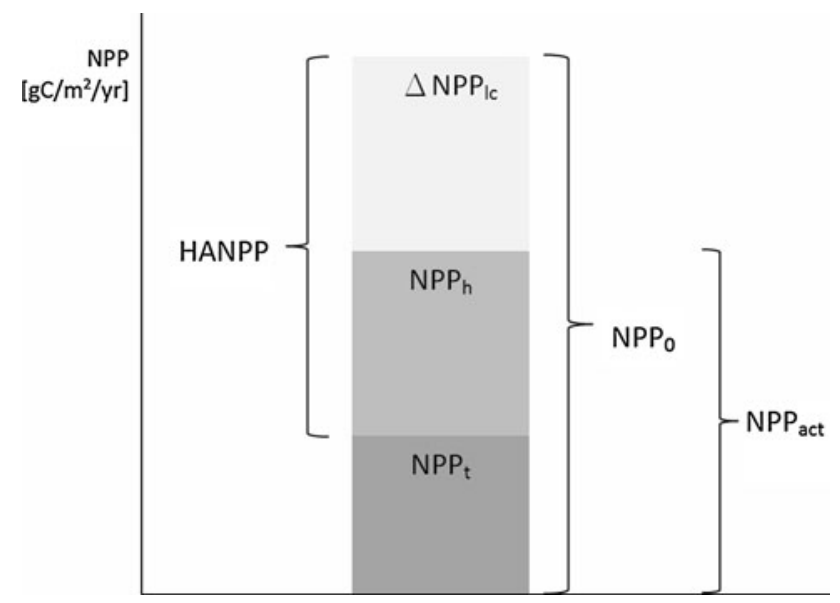

Fig. 1 Definition of HANPP. HANPP is defined the sum of land-useinduced NPP changes $\left(\triangle \mathrm{NPP}_{\mathrm{lc}}\right)$ and human harvest $\left(\mathrm{NPP}_{\mathrm{h}}\right)$, or as the difference between potential NPP $\left(\mathrm{NPP}_{0}\right)$ and the amount of NPP that remains in ecosystems after human harvest $\left(\mathrm{NPP}_{t}\right)$

economic systems that renders it a useful starting point of socio-ecological analyses (Krausmann et al. 2009a).

This study applies the HANPP concept as a means for empirically analysing land system change in the background of the socio-economic and political environment of South Africa from 1961 to 2005 . We aim at providing a socio-ecological analysis of the mechanisms and constraints underlying land system change. In this context, we use the HANPP framework as a starting point and complement this analysis with information and data on the changes in other, non-HANPP-related aspects of the South African socio-ecological system. By integrating an empirical HANPP assessment with socio-economic and political information, we aim to outline an integrated perception of the trajectories in the socio-ecological system that allows us to gain insights into patterns and drivers of land system change in this country.

The Republic of South Africa (RSA) is particularly suited as an exemplary case study, because it is characterized by a well-known, complex political history: The period between 1961 and 2006 encompasses globally ongoing trends such as agricultural modernization (De Klerk 1984) and increasing embeddedness in global markets. Moreover, in the last 45 years, South Africa has undergone a steep growth of its population, which tripled during this period (FAO 2010). It also underwent a severe economic and social crisis during the Apartheid regime, which ended in political collapse and resulted in democratic re-organizations after 1990 (Von Maltitz and Scholes 1995; Attridge and Jolly 1998; Kirsten et al. 2007; Coulibaly 2009).

At the same time, almost all of the South African ecosystems have been exposed to human land use. Almost the entire landscape can be considered as grazed by 
domestic livestock, and large areas of highly productive grasslands have been transformed into cropland, which, together with unsustainable land-use practices places pressure on the intactness of the prevalent savannah ecosystems (Von Maltitz and Scholes 1995). All this renders the RSA an interesting case for empirically studying the interrelations between land-use change and socioeconomic change.

\section{Materials and methods}

For the assessment of HANPP in a decadal time series, we here follow the definition proposed by Haberl et al. (2007) and Erb et al. (2009b). In this definition, HANPP is calculated as the sum of harvested biomass $\left(\mathrm{NPP}_{h}\right)$ plus the amount of biomass appropriated through alterations in productivity due to anthropogenic land use $\left(\Delta \mathrm{NPP}_{1 c}\right.$; see Fig. 1). As data availability is limited, we here only calculate and model above-ground fractions of HANPP. In consequence, we denote our results with the prefix 'a' (e.g. aHANPP, $\mathrm{aNPP}_{0}$, etc.).

We collected additional datasets for the socio-ecological analysis, comprising information on population growth, international trade of agricultural and forestry products, the degree of agricultural intensification and modernization (e.g. fertilizer inputs and agricultural yields) and GDP development. For all these variables, time series from 1961 to 2006 were compiled by making use of the FAO statistical database (2010) and the world development indicator database (World Bank 2010).

The empirical part of this study relies on data sets that have been compiled for the entire country at yearly intervals from 1961 to 2006. Data sets on land cover/land use, biomass harvest $\left(\mathrm{aNPP}_{\mathrm{h}}\right)$, potential net primary productivity $\left(\mathrm{aNPP}_{0}\right)$, productivity changes due to human intervention $\left(\triangle \mathrm{aNPP} \mathrm{lc}_{\mathrm{c}}\right)$ and actually prevailing net primary productivity $\left(\mathrm{aNPP}_{\mathrm{act}}\right.$ ) were established in order to assess HANPP. Primary data are based on national and international statistical records (including data on land use and crop harvest), as well as on the output of the dynamic vegetation model LPJ (Sitch et al. 2003; Bondeau et al. 2007; Haberl et al. 2007) for the assessment of the aNPP of potential vegetation. Many data were assessed on the grounds of both, country-specific primary data and generic data or assumptions, such as crop-straw ratios, feed demand of livestock, or pre-harvest loss factors. The yearly biomass flows were assessed in tons of carbon per year (tC/year), assuming a fraction of $50 \%$ carbon in dry biomass. The different components of the data set are shortly described below, detailed information on data sources and methods used are presented in the electronic supplementary material (ESM).

\section{Land cover/land use}

Yearly data on land cover/land use are a key requirement for HANPP time series assessments. Unfortunately, detailed information on land-cover/land-use change in the RSA is not readily available. Therefore, a mixed approach was chosen, combining the use of primary data and with modelling assumptions. First, a consistent set of 13 landuse/land-cover classes was established which differ in terms of their typical NPP. These classes can be aggregated to five land-use types (Table 1).

\section{Harvest $\left(\right.$ aNPP $\left._{h}\right)$}

In our definition, biomass harvest on cultivated areas consists of the total above-ground biomass of annual crops (which includes primary crop harvest, recovered and unrecovered crop residues), permanent crops (e.g. primary crop harvest and annual increment) and grazed biomass on fallow land. Data for these items were extracted from the datasets for cultivated land quoted in Table 1. A detailed documentation of methods and data sources is available in the electronic supplementary material (ESM).

No statistics exist for the amount of annually grazed biomass. Thus, grazed biomass was calculated as the difference between feed demand and feed supply on an annual basis (Krausmann et al. 2008). Feed demand was calculated as a function of animal produce, and market feed supply was derived from statistics. The amount of nonmarket feed was calculated by subtraction ('grazing gap'). For the HANPP calculation, the amount of grazing was then assigned to different land-use/land-cover categories following the allocation in Table 1, assuming that the share of grazing consumed on different land-use/land-cover classes depends on the extent and the potential of aboveground biomass production of these categories. Assumptions on grazing potential of landscapes most severely affected by grazing could be made through the grazingcapacity map (Agriculture Research Council-Institute for Soil Agriculture Maps of South Africa) and spatially explicit data on livestock densities (FAO 2007).

Harvest in forestry was calculated as the sum of wood removals reported in the national statistics and felling losses; the latter was assessed by applying wood-specific recovery rates (see ESM). Roundwood is assumed to be extracted from closed forests only.

In contrast, harvest of fuelwood can almost exclusively be assigned to open forests and thicket and bushland. No annual statistics on the amount of fuelwood extraction are available for the RSA, and different assumptions can be found in the literate (Gandar 1983; Banks et al. 1996; DME 1996; Williams and Shackleton 2002). In line with 
Table 1 Land-use and landcover classes with their main sources occurring in this study

\begin{tabular}{lll}
\hline Land-use class & Land-cover category & Sources \\
\hline Cultivated land & Fallow land & Own calculations \\
& Annual cropland & STATSA, Daff \\
& Permanent cropland & FAO, Daff, authors' calculations \\
Settlement area & Settlement area & FAO, NLC 1995, authors' \\
& & calculations \\
Forest land & Closed forests & STATSA, Daff \\
& Open forests & NLC 1995 \\
Grazing land & Grassland & NLC 1995 \\
& Shrub cover & NLC 1995, authors' calculations \\
& Sparse herbaceous and sparse shrub & NLC 1995, GLC 2000 \\
& cover & \\
& Low fynbos & NLC 1995, Acocks (1953) \\
& Undefined grazing land & Authors' calculations \\
Unused/unproductive & Thicket and bushland & NLC 1995 \\
land & Unused/unproductive land & (Erb et al. 2007), authors' \\
\hline
\end{tabular}

Williams and Shackleton (2002), we applied a constant per person demand of $0.12 \mathrm{tC} /$ cap/year to calculate fuelwood demand for the whole period.

Harvest on settlement areas, for example through gardening work and park or infrastructure maintenance, was assumed to be $50 \%$ of aNPP act of these areas (Haberl et al. 2007).

The amount of above-ground biomass appropriated through human-induced fires would represent a further $\mathrm{aNPP}_{\mathrm{h}}$ category (Lauk and Erb 2009), but was not included in the assessment, due to a lack of data and contradictory notions in the literature: human activities might have resulted in increases (spread of clearing fires) or decreases (fire prevention) of biomass flows related to human-induced vegetation fires (Erb et al. 2009b; Lauk and Erb 2009).

\section{Ecosystem productivity $\left(\mathbf{a N P P}_{\mathbf{0}}, \mathbf{a N P P}_{\text {act }}\right.$ and $\left.\Delta \mathrm{aNPP} \mathrm{P}_{\mathrm{lc}}\right)$}

Data on the time series of potential above-ground net primary production $\left(\mathrm{aNPP}_{0}\right)$ were taken from unpublished material of the global HANPP study for the year 2000 (Haberl et al. 2007). These data are based on a model output of the Lund-Potsdam-Jena Dynamic Global Vegetation Model (LPJ-DGVM; (Sitch et al. 2003) with an improved representation of hydrology (Gerten et al. 2004), using 100-year climate time series as input variables. For the aNPP0 time series, we calculated 5-year averages for each time step in order to eliminate fluctuations in the dataset. For further details on the land-use/land-coverspecific picture of $\mathrm{NPP}_{0}$, see the ESM.

The amount of NPP in the actually prevailing vegetation $\left(\mathrm{aNPP}_{\mathrm{act}}\right.$ ) was calculated the following way. For cropland, the total above-ground NPP was calculated by applying an expansion factor (of 1.33) to the $\mathrm{NPP}_{\mathrm{h}}$ data in order to calculate the amount of pre-harvest losses (e.g. losses due to herbivory). ANPP act of settlement areas was assumed to be one-third of $\mathrm{aNPP}_{0}$. $\mathrm{ANPP}_{\text {act }}$ of fallow cropland, closed forests and unused/unproductive land was assumed to be identical to $\mathrm{aNPP}_{0}$ (i.e. $\triangle \mathrm{NPP}_{\mathrm{lc}}$ was assumed to be zero on these land-use types; Haberl et al. 2007).

A particularly relevant component of $\triangle \mathrm{aNPPlc}$ are NPP reductions losses due to soil degradation (Zika and Erb 2009). Soil degradation in South Africa is controversially discussed. Several studies consider land degradation a substantial factor for the decline in productivity in South African ecosystems (Hoffman and Ashwell 1999; Bai and Dent 2007). Other authors confirm that human land use, such as overgrazing, plays a crucial role in putting pressure on the intactness of ecosystems, but simultaneously no major decrease in ecosystem functions could be detected in the past for several study sites mapped as degraded (Wessels et al. 2004; Palmer and Ainslie 2007). Older accounts of soil degradation assert South Africa to be severely affected (Oldeman 1988), assumptions that have meanwhile been revised (JRC 2003). The NLC 1995 (Fairbanks et al. 2000) provides information on the extent of degraded areas per land-cover type. Degraded areas are defined as areas suffering from severe vegetation cover and productivity loss compared to their surrounding areas (Fairbanks et al. 2000). On the basis of a study on soil degradation in drylands using this information (Zika and Erb 2009), we assume that areas suffering from severe degradation (degree 3 and 4) experience a mean productivity loss of $56 \%$ of aNPP ${ }_{0}$. We thus apply a $\triangle \mathrm{aNPP}_{\mathrm{lc}}$ level of $56 \%$ of the original $\mathrm{aNPP}_{0}$ for areas mapped as degraded in the NLC 1995. Unfortunately, no datasets or appropriate methods are available that would allow to infer the 
dynamics of soil degradation-induced NPP losses appropriately in a 45 -year time series, neither on the changes in extent nor on changes in the degree of degradation. Thus, in our approximation, we consider degradation-induced $\Delta \mathrm{aNPP} \mathrm{lc}_{\mathrm{c}} / \mathrm{m}^{2}$ on all land classes used for grazing and on open forests (which are also subjected to human-induced degradation; Fairbanks et al. 2000) constant over the whole period under investigation. As a result, it is important to note that the effect of soil degradation in the RSA remains only roughly addressed in this HANPP study.

\section{Data integration}

In a next step, we integrate the findings of the HANPP assessment with information on socio-economic developments, such as political shifts, population growth, GDP and trade developments recorded for the RSA in the investigated time span. We develop a socio-ecological time line that covers the whole period under investigation and allows to identify interrelations between different developments in the socio-ecological system of South Africa.

\section{Results}

\section{HANPP}

Figure 2 illustrates changes in land use and land cover in the RSA between 1961 and 2006. Throughout the entire time period, land not used for forestry, for cultivation, for settlement, and land not identified as unused/unproductive dominated the land surface, making up between 72 and $76 \%$ of total land area. This land bears ecosystems like savannahs, semi-deserts and grasslands, and most of this land is used for grazing, although sometimes very extensively (Erb et al. 2007; therefore, we denoted it grazing land). Cultivated land was the second most important land-

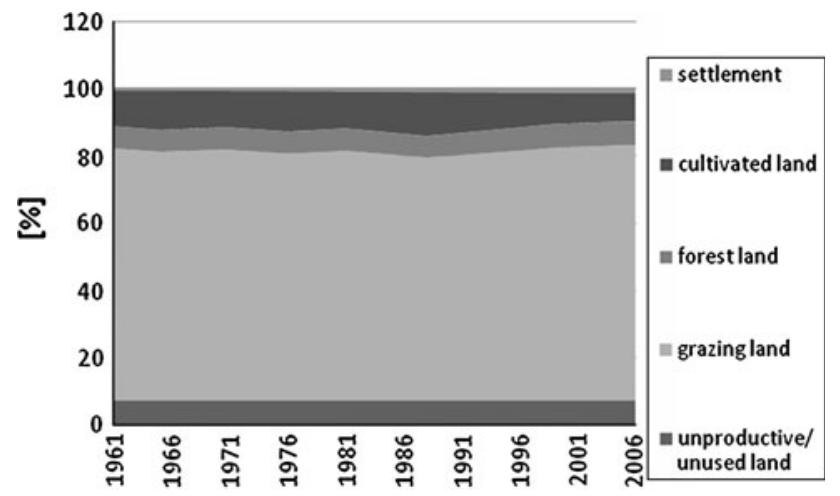

Fig. 2 Land-cover/land-use change in South Africa from 1961 to 2006 use category, followed by forest land. Unused/unproductive land and settlement areas were of minor importance in terms of land-use extent.

Cropland expansion and decline, the spread of settlement areas and the spread of forest plantations had the strongest effects on land-use/land-cover change in South Africa in the observed period. However, the relatively small share of these land-use types (around 12\% in most years), as well as the low rates of change, resulted in relatively stable land-cover conditions throughout the time period. In 1988, the sum of settlement areas, cultivated land and forest plantations peaked at almost $16 \%$ of the total land area, mainly due to expanding cropland. Grassland was the land-cover class that exhibited the most pronounced changes. In the period from 1961 to 1988, grassland areas declined from 270,000 to $250,000 \mathrm{~km}^{2}$, mainly due to the expansion of cultivated areas. Due to a decrease in cultivated areas from 1988 onwards, grassland reached the initial level of 1961 again in recent years, with values around $270,000 \mathrm{~km}^{2}$. All other land-cover classes only show slight changes in area extent.

Figure 3 displays the development of the different HANPP components over time, the three components $\mathrm{aNPP}_{\mathrm{t}}, \Delta \mathrm{aNPP} \mathrm{lc}_{\mathrm{c}}$ and $\mathrm{aNPP}_{\mathrm{h}}$ summing up to $\mathrm{aNPP}_{0}$. According to the results of the LPJ global dynamic vegetation model, total $\mathrm{aNPP}_{0}$ (the potential above-ground net primary productivity) shows a pronounced dynamic over the investigated time period. It declined from 304 to 288 million tons carbon per year (MtC/year) over the entire period between 1961 and 2006, with a decrease in the first decade, a steep increase until the year 2000, and a decline afterwards. In the year $2000, \mathrm{aNPP}_{0}$ peaked at $379 \mathrm{MtC} /$ year. This high value can be attributed to unusual high precipitation on large areas of Northern and Eastern South Africa, which boosted productivity of many ecosystems. This period was followed by a much drier period (Laing 1994; Dyson and Van Heerden 2001; Alexander 2002; Rouault and Richard 2005) that resulted in a steady decline

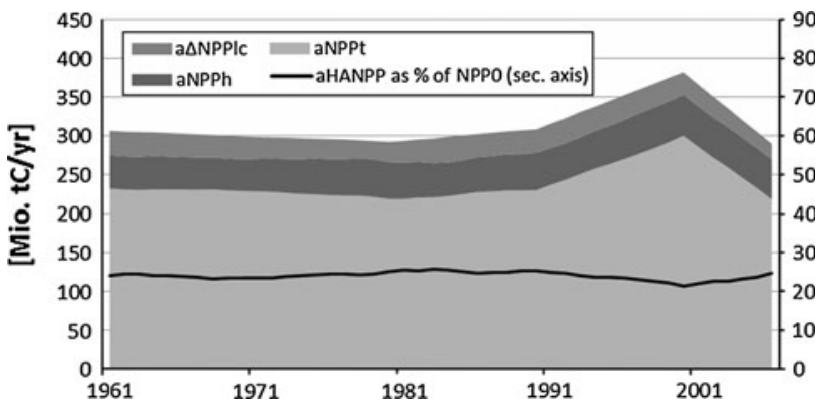

Fig. 3 HANPP trajectories 1961-2006, breakdown to main components. aHANPP as percentage of $\mathrm{aNPP}_{0}$ (solid black line) is drawn against the secondary axis 
in $\mathrm{aNPP}_{0}$ after 2000. However, as the HANPP approach we follow here is optimized in assessing differences between aNPP0 and single HANPP components, this data uncertainty of $\mathrm{NPP}_{0}$ is to a large extent cancelled out in the aHANPP assessment. As a result, $\mathrm{aNPP}_{\mathrm{t}}$ closely follows the $\mathrm{aNPP}_{0}$ trend, and HANPP, expressed in $\%$ of $\mathrm{NPP}_{0}$, does not show this particular pattern.

The development of aNPP ${ }_{\mathrm{h}}$ and $\triangle \mathrm{aNPP}_{\mathrm{lc}}$ was not very pronounced over the last four decades, it remained at levels of around 41-53 mio tC/year (around 15\% of aNPP ${ }_{0}$ ) and

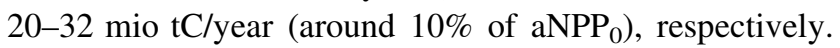
In consequences, aHANPP fluctuated between 21 and $25 \%$ over the whole period under investigation, with a minimum around the year 2000, which is a result of extraordinarily high productivity levels in this year.

Biomass extraction through anthropogenic harvest $\left(\mathrm{aNPP}_{\mathrm{h}}\right.$ ) rose by $28 \%$ between 1961 and 2006, from around 40 mio tC/year to more than 51 mio tC/year (Fig. 4a). A peak of 46 mio tC/year was observed in 1978, which was the result of above average production on cultivated land. Harvest on cultivated land contributes the lion's share to total harvest; it increased continuously from 15 mio tC/year in 1961 to around 27 mio tC/year (41\% of total $\mathrm{aNPP}_{\mathrm{h}}$ ) in 1978 with a decline until 1984 and a slight rise afterwards. Due to a smaller share of crop residues, market feed and non-market feed (fodder crops) to total feed supply, the amount of grazed biomass was higher in the 1960s, compared to the following decades. Declining amounts of grazed biomass per year can also be interpreted as the result of rising commercialisation and modernisation of the livestock industry, associated with gains in inputoutput efficiency. From the mid-1980s onwards, grazing increased again. Harvest on forest land increased from around $4 \mathrm{MtC} /$ year in 1961 to around $10 \mathrm{MtC} /$ year in 2006.

Harvest per square metre of cultivated land increased from $130 \mathrm{gC} / \mathrm{m}^{2} /$ year in 1961 to around $210 \mathrm{MtC} /$ year at the end of the investigated time period (Fig. 4b). A peak of $200 \mathrm{gC} / \mathrm{m}^{2} /$ year was observed in 1979 , followed by a drastic decline afterwards. Harvest per $\mathrm{m}^{2}$ of forest land continuously rose from $60 \mathrm{gC} / \mathrm{m}^{2} /$ year in 1961 to around $140 \mathrm{gC} /$ $\mathrm{m}^{2} /$ year in 1997 and slightly declined afterwards (Fig. 4b). Dynamics of grazing land are much smaller, with values remaining between 13 and $21 \mathrm{gC} / \mathrm{m}^{2} /$ year. Harvest on settlement areas continuously rose from 30 to $34 \mathrm{gC} / \mathrm{m}^{2} /$ year.

Much more pronounced was the development of $\triangle \mathrm{aNPP} \mathrm{lc}_{\mathrm{c}}$ in the period of regard (Fig. 4c). Values declined from 31 to 22 mio tC/year in the period from 1961 to 1978 and afterwards rose again to its highest level of 33 mio tC/ year in 1984. After 2000, a steep characterizes the development of $\triangle \mathrm{aNPP}_{1 \mathrm{c}}$. Cultivated land accounted for most of the temporal trends of $\Delta \mathrm{aNPP}_{\mathrm{lc}}$, both due to fluctuations in annual crop yields and land-use change. $\triangle \mathrm{aNPP}_{\mathrm{lc}}$ values on cultivated land were around $16 \mathrm{MtC} /$ year in the early $1960 \mathrm{~s}$ and dropped to around $8 \mathrm{MtC} /$ year in 1979, reached a maximum of $18 \mathrm{MtC} / \mathrm{year}$ in the early 1980s and reached a minimum in 1994 with $3 \mathrm{MtC} / \mathrm{year}$ at the end of the investigated time period. $\triangle \mathrm{aNPP} \mathrm{lc}_{\mathrm{cc}}$ on grazing and forest land is attributed only to land degradation and is fairly constant at 11 and $2 \mathrm{MtC} /$ year, respectively. $\triangle \mathrm{aNPP}_{\mathrm{lc}}$ on settlement area increased fourfold, from around 1 to $4 \mathrm{MtC} /$
Fig. 4 Development of aHANPP components between 1961 and 2005, break down to land-use types. $\mathrm{a} \mathrm{aNPP}_{\mathrm{h}}$ in mio tC/year, b aNPP ${ }_{\mathrm{h}}$ in $\mathrm{gC} / \mathrm{m}^{2} /$ year, $\mathbf{c} a \Delta \mathrm{NPP}_{\mathrm{lc}}$ in mio tC/year, d a $\Delta \mathrm{NPP}_{\mathrm{lc}}$ in $\mathrm{gC} / \mathrm{m}^{2} /$ year
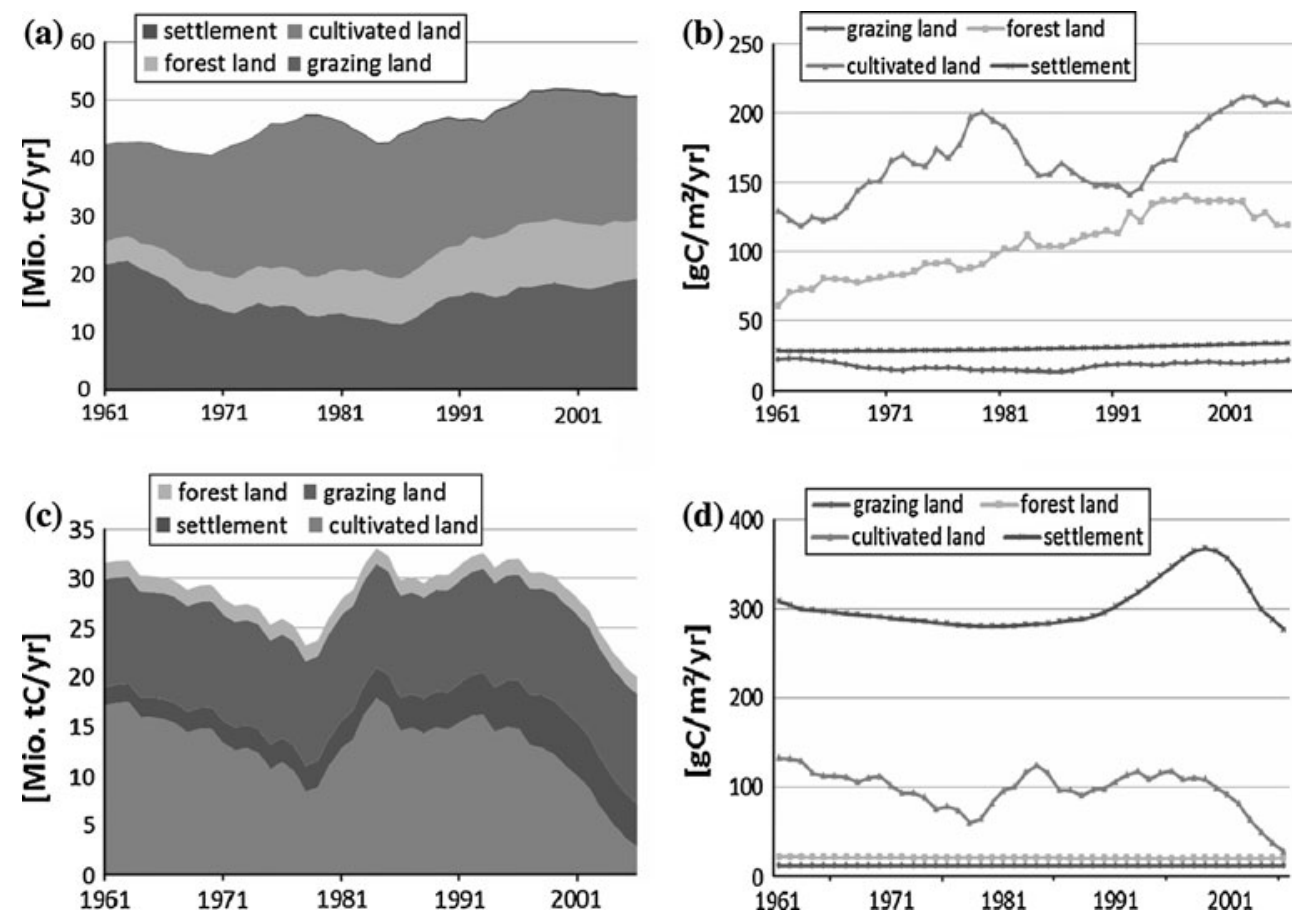
year, but plays a minor role. This land-use class, however, shows the highest values of $\triangle \mathrm{aNPP}_{\mathrm{lc}}$ per land unit (Fig. 4d) (between 280 and $370 \mathrm{gC} / \mathrm{m}^{2} /$ year), closely following the $\mathrm{aNPP}_{0}$ dynamics (Fig. 3: HANPP trajectories 1961-2006, breakdown to main components.). $\Delta \mathrm{aNPP}_{\mathrm{lc}} / \mathrm{m}^{2} /$ year fluctuates between 125 and $28 \mathrm{gC} / \mathrm{m}^{2} /$ year, with a steep decline after 1998. As noted in the method section, $\Delta \mathrm{aNPP} \mathrm{lc}_{\mathrm{c}} / \mathrm{m}^{2}$ due to soil degradation (accounted for in the various categories of grazing land forest land) was assumed to be constant. Therefore, forest land and grazing land remained at steady levels of around 20 and $12 \mathrm{gC} / \mathrm{m}^{2} /$ year respectively throughout the whole period under investigation.

\section{Socio-ecological analysis}

Scrutinizing the patterns of HANPP, three different phases of development can be distinguished. These phases appear to be well in line with major periods of socioeconomic and political development in the RSA. We define these periods in their chronological order as 'Green Revolution', 'economic and political crisis' and 'democratic opening'. Figure presents a synoptic view on the developments of various socio-ecological parameters. This allows for studying the incidence of shifts of aHANPP and its parameters with socio-economic developments and milestones. All the findings discussed below have to be considered in the light of an enormous increase of societal biomass demand, driven by an almost threefold population growth from 18 to 49 million people in the observed time period (FAO 2010).

\section{Green revolution}

The first 'Green Revolution' period between 1961 and 1980 was characterized by growth of agricultural productivity, due to fast modernization of cultivation practices. State subsidies on the cultivation of land (Kirsten et al. 2007) allowed for an expansion of cultivated land into marginal areas and for increasing agricultural output per unit of cropped area (FAO 2005). This led to an increasing share of biomass harvest (aNPPh) to total aHANPP and a simultaneous decrease in the share of $\triangle \mathrm{aNPPlc}$, resulting in a moderate rise in land-use efficiency until 1978 (Fig. 5a). The rise in average crop yields (Fig. 5c) can be attributed to the accelerating intensity of agricultural land use. Annual fluctuations in crop yields can be attributed to climatic variability as well (Rouault and Richard 2005). Consumption of fertilizers per land unit (Fig. 5c) was about five times higher in the late 1970s than in 1961. The use of agricultural machinery increased considerably, thus replacing draft animals for agricultural purposes to a large extent (not displayed in the figure). In the late 1960s, the introduction of combined harvesters triggered a decrease in demand for agricultural labour and thus reduced the number of farm employees from the mid 1970s onwards (Kirsten et al. 2007).

In this phase of agricultural and economic growth, the nutritional situation of the South African population improved significantly (not shown). Kcal/cap/day intake of vegetable and animal products increased from 2,800 to $3,000 \mathrm{kcal}$ in the mid 1970s (own calculations; FAO 2010, Fig. 5b), accompanied with a transition towards more protein- and fat-based alimentation (Bourne et al. 2002).

The major economic positions of the Apartheid regime, economic independency and antitrade strategy, were pursued by a complex system of import substitution and export taxation (Kirsten et al. 2007). During the 1960 and 1970s, South Africa was an exporting country of forestry and agricultural biomass, while imports remained at very low levels (Fig. 5d). Annual GDP growth rates, extremely high at the beginning of the period, started to decline from the early 1970s onwards and by 1976, the economy moved into a state of recession with annual growth rates below 1 per cent (Kirsten et al. 2007). In this period, the share of agriculture to GDP declined from 12\% in 1961 to $6 \%$ in 1978 (Fig. 5c), values that can be found in countries of the Industrial world, indicating a period of strong agricultural modernization and the development of off-farm employment.

\section{Political and economic crisis}

In 1980, the period of agricultural growth was brought to an immediate halt, and a period of instability and complex fluctuations followed until 1995 (Fig. 5). $\mathrm{ANPP}_{\mathrm{h}}$ decreased after a peak in 1978 and simultaneously, $\triangle \mathrm{aNPP}_{\mathrm{lc}}$ increased, resulting in a considerable drop of land-use efficiency in 1984, back to the levels of the early 1960 s (Fig. 5a). This reduction of land-use efficiency was, however, not associated with a reduction in the use of means of production. In contrast, a peak in mineral fertilizer consumption was accompanied with shrinking cropland yields (Fig. 5c). Biomass imports started to increase in this period, and for two points in time (1982 and 1992), the RSA turned into a net import country of biomass (Fig. 5d). This can be interpreted as the combined effect of the steep population increase from 29 to 40 million people within this period (Fig. 5b), and the disability of the RSA to maintain self-sufficiency at times of the two extreme drought events of 1982 and 1992 (Laing 1994; Rouault and Richard 2005). In this phase, kcal intake per person remained at around 3,000 kcal/cap/day (own calculations; FAO 2010; Fig. 5b).

The political crisis in the period from 1979 until 1994 (the year of the official end of Apartheid), characterised by a slow-down in economic performance (Fig. 5e), 


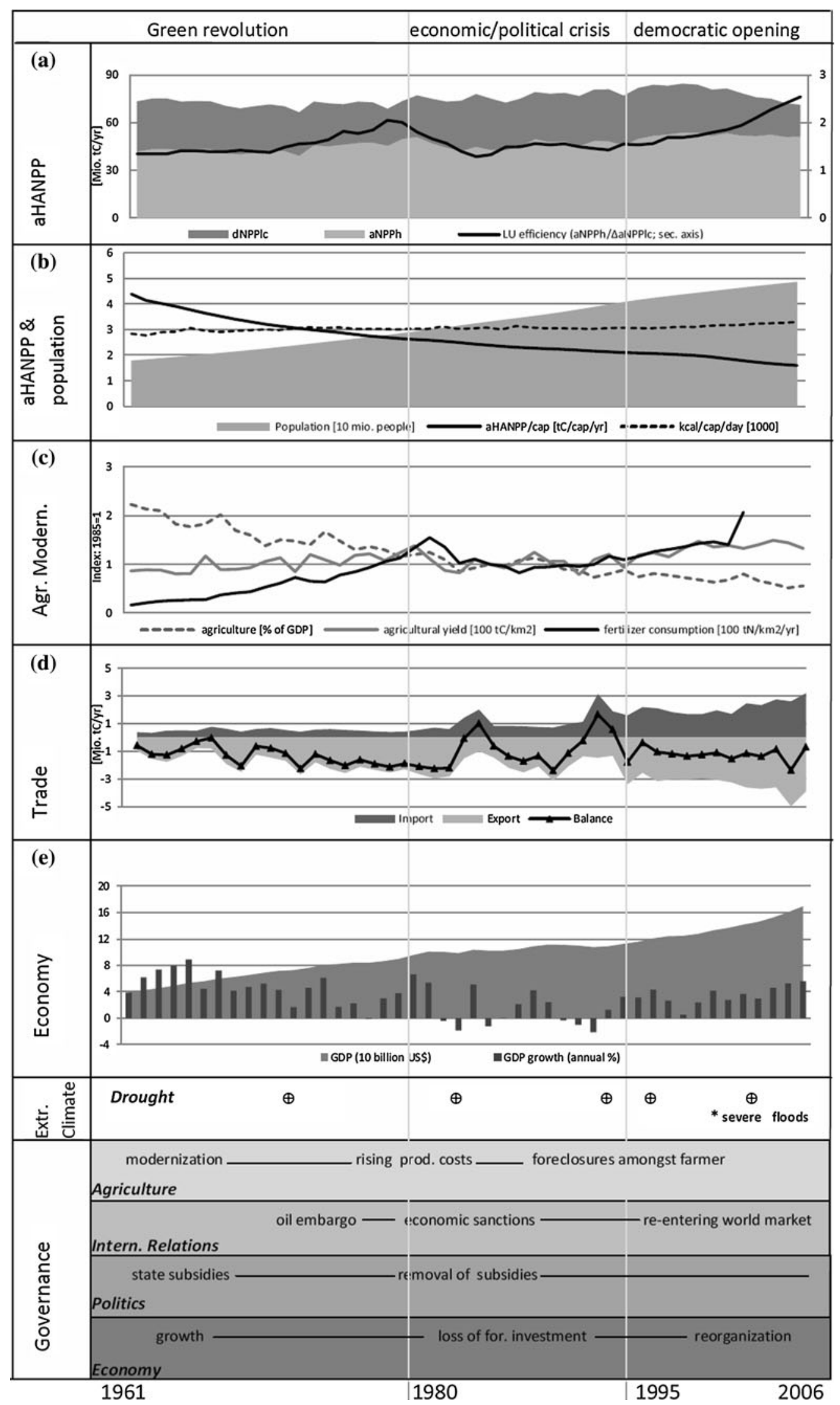

Fig. 5 Time line for main trajectories of aHANPP, population, trade of biomass, climatic extreme events and governance implementations 
experienced a stagnation of agricultural development which is reflected by a rise in $\triangle \mathrm{aNPP}_{\mathrm{c}}$ and a decrease in land-use efficiency. It is argued in the literature (Kirsten et al. 2007) that the combination of agricultural state support and the high costs of the distortive price system of Apartheid made the agricultural sector inflexible and vulnerable, in particular from the 1980s onwards. After a peak of state support in the early 1980s, subsidies on agricultural production started to decline rapidly, as the government was no longer able to maintain the high expenditures for overregulation of the agricultural price system (Kirsten et al. 2007). The reduction of governmental subsidies, the removal of the rebate on diesel (Simbi and Aliber 2000), as well as decelerated effects of the oil embargo (Levy 1999), boosted agricultural production costs for farmers and reduced agricultural performance. This is well illustrated by the reduction in agricultural performance (Fig. 5c; reduction of fertilizer consumption and agricultural yields after 1981), as well as by the decrease of the area under cultivation, which began in the early 1990s (see Fig. 2). The share of grazing to total aHANPP increased in the crisis period; this may be attributed to a declined availability of crop residues for animal feed which was compensated by grazing (Fig. 4).

The slowdown of agricultural performance coincided with the onset of international sanctions against the Apartheid regime. South Africa's international offside position and domestic political unrest (Ndlovu 1998; Levy 1999; Kirsten et al. 2007) made it an unappealing country for foreign investment (Lundahl 1984). Economic performance slowed down considerably and GDP growth dropped to below zero in 1982. The South African debt crisis in 1985 (Michie and Padayachee 1998; Habib and Padayachee 2000) contributed to the collapse of the economic and political system in the late 1980 s and to the democratic transition, starting in the early 1990s.

\section{Democratic opening}

Rising international pressure (Coulibaly 2009), resistance movements within the country and the economic catastrophe finally led to the 'democratic opening' in the early 1990s. The first democratic elections were overwhelmingly won by the ANC (African National Congress) in 1994. Immediately afterwards, South Africa re-entered the global market and joined the World Trade Union. The ANC committed to a neo-liberal growth strategy with new legislations on privatisation and liberalisation of the financial and trade sector as part of the GEAR strategy (Habib and Padayachee 2000).

Analysing the development of HANPP and its components reveals that this period is characterized by resuming trajectories that prevailed in the 'green revolution' phase and characterize the development of land use also in other parts of the world, for example the UK, Spain, Austria (Krausmann et al. 2004; Schwarzlmüller 2009; Musel 2009). A similar trajectory is described for Hungary, a country that also experienced the collapse of the economic and governance structures during the collapse of the planned economy of the socialist period (Kohlheb and Krausmann 2009). From the mid 1990s onwards, agricultural production intensified again, inputs of mineral fertilizers as well as agricultural output per unit of cropped land increased again (Fig. 5c). This relaxation of the economic and political crisis was accompanied with increases in GDP growth that reached a level of 3\% in 1995 (e). Harvest, in particular on cropland, increased, accompanied by declining $\Delta \mathrm{aNPP}_{\mathrm{lc}}$, leading to increasing land-use efficiency (Fig. 5a).

However, the continuously rising demand for agricultural products within the country, as a result of the population increases to around 49 million people in 2006 (Fig. 5b) by far, outgrew the only slightly increasing harvest levels on cropland. Thus, after a slight decline in the first years of the post-Apartheid era, imports of biomass further increase, reaching levels in 2006 around 14 times as high as in 1961 (Fig. 5c). The Biomass exports accelerated as well, in particular of the forestry sector. Also kcal intake per person and year started to increase again shortly after the democratic opening and reached $3,300 \mathrm{kcal} / \mathrm{cap} /$ day in the year 2006 (own calculations; FAO 2010; Fig. 5b).

The agricultural sector could not fully recover from the crisis phase: the area under crop production continued to decline further until 2006 (Fig. 2). A reason for this can be found in the still prevailing price distortions caused by the complex trade system of Apartheid, and the insufficient programs that aimed at redistributing land and supporting rural development (Kirsten et al. 2007; Hérault and Thurlow 2009). Furthermore, the removal of state supports on agricultural production still remained an obstacle for the development of a sufficient small holder sector (Lahiff and Cousins 2005). New labour legislations increased the costs of agricultural employment and thus triggered a drastic decline of the number of regular farm employees after 1990 (Sparrow et al. 2008).

Regardless of the phases of development, per capita values of aHANPP steadily declined, from 4.1 tons of Carbon per capita and year in 1961 to $1.5 \mathrm{tC} / \mathrm{cap} /$ year in 2006. This steep decrease by $60 \%$ (Fig. 5b) can be attributed to the relatively constant level of aHANPP compared to steep population growth from 18 to 49 millions of people between 1961 and 2006. Apparently, South Africa followed a different trajectory than the Philippines, where similar rates of population growth lead to steep increases of HANPP, deforestation, and triggered surges in land-use efficiency (Kastner 2009). However, the South African 
HANPP assets do not necessarily indicate that human impacts on South African ecosystems were low and did not change over the last decades, for the HANPP approach does not allow for analysing changes of biophysical conditions (e.g. ecosystem functions and biodiversity) in detail.

\section{Discussion}

Between 1961 and 2006, humans appropriated around $21-25 \%$ of the potential above-ground biomass productivity in South African ecosystems, which equals a value between 72 and $83 \mathrm{MtC} /$ year. This result is low compared to the global average of $29 \%$ in the year 2000, calculated by Haberl et al. (2007) for above-ground NPP, and particularly low when compared to European, and especially Western European countries: average Western European aHANPP values are around $46.5 \%$, and for Spain, a country also bearing dryland ecosystems, aHANPP level of $61 \%$ are found (Schwarzlmüller 2009).

$\triangle \mathrm{aNPP}_{\mathrm{lc}}$ values in the RSA are found to be between 7 and $11 \%$ of total $\mathrm{aNPP}_{0}$ and are thus well in line with the global average of $5.2 \%$. Compared with $24 \%$ in Spain, however, the South African $\triangle \mathrm{aNPP}_{\mathrm{lc}}$ level seems rather low.

We can, however, not completely rule out an underestimation of total biomass appropriation in this study, because we strictly followed a conservative approach in the light of the many data uncertainties and thus could not assess the effects of land degradation and human-induced fires as precisely as desired. The availability of quantitative degradation data is probably better in South Africa than in other parts of the world (Zika and Erb 2009); however, the lack of inter-comparable historic data on degradation limited our ability to trace back $\triangle$ aNPPlc on grazing areas. Nevertheless, it can be concluded that the overall trends of aHANPP will not severely be affected by this underestimation: The contribution of $\triangle \mathrm{aNPPlc}$ to HANPP on grazing lands remains moderate throughout the time period (14\% of total aHANPP in 2000, the year with the best data availability), and the probable data uncertainties are thus unlikely to significantly alter the observed overall trends. Hence, we are confident that the conclusions we can draw out of the results for the socio-ecological analysis presented here are still reliable, and the trends and patterns of change we discerned can provide a pivotal contribution to the land system science.

In addition, data availability did not allow for tracing back biomass flows related to human-induced fires, and there is no empirical information available that would even allow to determine whether this biomass flow increased or decreased with population growth and agricultural development (Erb et al. 2009b). This aspect of land use represents an important subject for further research in order to improve our understanding of this global sustainability challenge (Verstraete et al. 2009).

Although aHANPP as percentage of $\mathrm{aNPP}_{0}$ does not show noticeable fluctuations over time, but was rather low and stagnant, this does not serve as evidence for negligible changes in the land system of the RSA. In contrast, aHANPP trajectories show some striking turning points during the last decades. These patterns become evident when calculating proportional changes of related HANPP parameters. In particular, the ratio of $\mathrm{NPP}_{\mathrm{h}}$ to $\triangle \mathrm{aNPP}$ c, which can be interpreted as an efficiency measure of land use (Erb et al. 2009b), shows a remarkable pattern and significant fluctuations during the period under investigation. The trend in land-use efficiency is a stringent indicator for the state of the land system, which in the South African case was influenced chiefly by the political and economic circumstances in the past four decades. The growth in land-use efficiency in the 'Green Revolution' period was disrupted abruptly with the onset of the political and economic crisis of Apartheid. However, after the democratic opening, patterns of land system change exhibited similarities to the former growth period, and land-use efficiency experienced a historic increase by $66 \%$ from 1994 to 2005. This was mainly a result of declining $\triangle \mathrm{aNPPlc}$ levels and rising harvest per $\mathrm{m} 2$ on cropland through increased fertilizer application (Fig. 5c).

The stagnant aHANPP trend compared to the drastic surges in population and thus biomass demand is only to a small extent based on a dislocation of environmental pressures to other, distant locations of the world. Biomass imports indeed increased throughout the whole period under investigation, thus relocating aHANPP to other countries. In particular, meat imports, which imply huge embodied HANPP flows in the exporting countries (Erb et al. 2009a; Haberl et al. 2009), drastically accelerated until 2006 (not shown), thus reducing environmental pressure due to meat production within the country boarders. However, trade involves only modest flows compared to overall $\mathrm{NPP}_{\mathrm{h}}$, and thus these 'problem-shifting' effects of trade only can provide a partial explanation. Analysing the effects of biomass trade on aHANPP in the RSA in detail is beyond the scope of this paper, but the empirical results call for methodologies that are able to consistently grasp this aspect of global land-use change (Erb et al. 2009a; Haberl et al. 2009; Kastner et al. 2011). Neither can a 'pauperization', that is a decreasing provision with nutritional energy, be held responsible for this steep reduction in per capita aHANPP, as caloric intake per capita is even increasing in the period of regard (Bourne et al. 2002) (with a stagnation only in the collapse phase). This all pinpoints to increases of land use and conversion efficiencies as a major driver of the 
'decoupling' between HANPP, population growth and biomass consumption in the RSA.

In order to assess the impact of human land use on South African ecosystems more precisely, the findings presented here could be considerably enriched by further research on the interrelations between our HANPP findings and the rich body of empirical research regarding natural conservation issues that has already been conducted for South Africa (Rouget et al. 2003; Scholes and Biggs 2005; VanJaarsveld et al. 2005).

\section{Conclusion}

The consistent and stringent framework of the HANPP assessments, when consistently combined with socio-economic information, allows for empirical analyses of the mutual links between resource systems, the resources they provide and the socioeconomic system, and so allows studying drivers and impacts of technological and global environmental changes. The stringency and consistency of the HANPP framework allows generating robust insights into the interlinkages between social and ecological systems, even in the light of the large uncertainties related to some of the datasets.

Whereas land-cover changes in the RSA have not been very pronounced in the last four decades, the HANPP framework helps to detect subtle changes in the land system and provides a tool to link developments in social, political and economic factors with land system change. Examinations of the development of land-use efficiency (i.e. the ratio between overall aHANPP and harvest) vividly illustrate the effects of a political crisis on the land system. As neither shifts towards dependency on foreign land resources, nor pauperization holds as an explanation for the decline in aHANPP per person trend, this entails that noteworthy increases of biomass use efficiency are the predominant mechanism underlying this development. Apparently, large potentials exist to 'decouple' the use of ecosystem services from ecological impacts, for example by technological improvements. For avoiding rebound effects, however, strategies that aim at technological developments have to rely on integrated perspectives, aimed at optimizing production and consumption systems at the same time. Integrated indicator frameworks, such as the HANPP framework, can provide a useful starting point for such integrated analyses. Combinations of robust quantitative information with more qualitative information can so represent a valuable contribution to sustainability science (Kates et al. 2001; Ostrom 2007).

Acknowledgments Our special thanks go to Helmut Haberl from the Institute of Social Ecology in Vienna for his supportive help and useful comments concerning the empirical work as well as the writing of this paper. Many thanks to Bob Scholes for his hospitality, the many discussions and insightful comments, to Marna van der Merve, Sally Archibald, Toni Palmer, Tim Hoffman and Graham von Maltitz for the help with data and their inputs. This work has benefited from the Global Land Project (http://www.globallandproject.org), as well as from research funded by the Austrian Science Fund (project P20812-G11). Funding from the ERC Project LUISE (263522) is gratefully acknowledged.

Open Access This article is distributed under the terms of the Creative Commons Attribution License which permits any use, distribution, and reproduction in any medium, provided the original author(s) and the source are credited.

\section{References}

Acocks JP (1953) Veld types of South Africa. In: Memoirs of the Botanical Survey of South Africa 28, p 192

Alexander WJR (2002) Statistical analysis of extreme floods. J S Afr Inst Civil Eng 44(1):20-25

Attridge D, Jolly RJ (1998) Writing South Africa: literature, apartheid, and democracy 1970-1995. Cambridge University Press, Cambridge

Ayres RU (2007) On the practical limits to substitution. Ecol Econ 61:115-128

Bai ZG, Dent DL (2007) Land degradation and improvement in South Africa 1. Identification by remote sensing. Report 2007/03. I.-W. S. Information, Wageningen

Banks DI, Griffin NJ et al (1996) Wood supply and demand around two rural settlements in a semi-arid Savanna, South Africa. Biomass Bioenergy 11:319-331

Bondeau A, Smith PC et al (2007) Modelling the role of agriculture for the 20th century global terrestrial carbon balance. Glob Change Biol 13(3):679-706

Bourne LT, Lambert EV et al (2002) Where does the black population of South Africa stand on the nutrition transition? Public Health Nutr 5(1A):157-167

Coulibaly B (2009) Effects of financial autarky and integration: the case of the South Africa embargo. J Int Money Finance 28:454

De Klerk W (1984) Seasons that will never return: the impact of farm mechanization on employment, incomes and population distribution in the western transvaal. J South Afr Stud 11(1):84-105

DME (1996) Energy in South Africa. Department of Minerals and Energy, Pretoria

Dyson LL, Van Heerden J (2001) The heavy rainfall and floods over the northeastern interior of South Africa during February 2000. S Afr J Sci 97(3 \& 4):80-86

Erb KH, Gaube V et al (2007) A comprehensive global 5 min resolution land-use data set for the year 2000 consistent with national census data. J Land Use Sci 2(3):191

Erb K-H, Krausmann F et al (2009a) Embodied HANPP: mapping the spatial disconnect between global biomass production and consumption. Ecol Econ 69(2):328-334

Erb KH, Krausmann F et al (2009b) Analyzing the global human appropriation of net primary production-processes, trajectories, implications. An introduction. Ecol Econ 69(2):250-259

ESRI map books. Agriculture Maps of South Africa, Grazing Capacity Map. Map Book Gallery Volume 19. Available at: http://www.esri.com/mapmuseum/mapbook_gallery/volume19/ agriculture3.html. Downloaded on 12 May 2011

Evans L (1993) Harvest index. Crop evolution, adaption and yield. L. Evans, Cambridge, pp 238-260 
Fairbanks DHK, Thompson MW et al (2000) The South African landcover characteristics database: a synopsis of the landscape. S Afr J Sci 96:69

FAO (2005) Fertilizer use by crop in South Africa. FAO, Rome

FAO (2007) Gridded livestock of the world 2007. In: Wint GRW, Robinson T (eds), Rome, Food and Agricultural Organisation of the United Nations (FAO), p 131

FAO (2010) FAOSTAT 2010, Food and Agriculture Organization of the United Nations (FAO)

Foley JA, Monfreda C et al (2007) Our share of the planetary pie. Proc Natl Acad Sci 104(31):12585-12586

Gandar MV (1983) Wood as a source of fuel in South Africa. Pietermaritzburg

Gerten D, Schaphoff S et al (2004) Terrestrial vegetation and water balance-hydrological evaluation of a dynamic global vegetation model. J Hydrol 286:249

GLP (2005) Science plan and implementation strategy. Global Land Project, Stockholm

Haberl H (1997) Human appropriation of net primary production as an environmental indicator: implications for sustainable development. Ambio 26:143

Haberl H, Fischer-Kowalski M et al (2004a) Progress towards sustainability? What the conceptual framework of material and energy flow accounting (MEFA) can offer. Land Use Policy 21:199-213

Haberl H, Wackernagel $\mathrm{M}$ et al (2004b) Land use and sustainability indicators. An introduction. Land Use Policy 21(3):193-198

Haberl H, Erb KH et al (2007) Quantifying and mapping the human appropriation of net primary production in earth's terrestrial ecosystems. PNAS 104(31):12942-12947

Haberl H, Erb K-H et al (2009) Using embodied HANPP to analyze teleconnections in the global land system: conceptual considerations. Dan J Geogr 109(2):119-130

Habib A, Padayachee V (2000) Economic policy and power relations in South Africa's transition to democracy. World Dev 28(2):245-263

Hák T, Moldan B et al (2007) Sustainabiltiy indicators: a scientific assessment. Island Press, Washington

Hérault N, Thurlow J (2009) Agricultural distortions, poverty and inequality in South Africa. Agricultural distortion working paper 104. World Bank

Hoffman T, Ashwell A (1999) Nature divided: land degradation in South Africa. Cape Town

JRC (2003) Global land cover 2000 database, European Commission, Joint Research Centre

Kastner T (2009) Trajectories in human domination of ecosystems: Human appropriation of net primary production in the Philippines during the 20th century. Ecol Econ 69(2):160-169

Kastner T, Erb K-H et al (2011) International wood trade and forest change: a global analysis. Glob Environ Change 21(3):947-956

Kates RW, Clark WC et al (2001) Sustainability science. Science 292(5517):641-642

Kirsten J, Edwards L et al (2007) Distortions to agricultural incentives in South Africa. Agricultural distortion working paper 38. World Bank

Kohlheb N, Krausmann F (2009) Land use change, biomass production and HANPP: the case of Hungary 1961-2005. Ecol Econ 69(2):292-300

Krausmann F, Haberl H et al (2004) Resource flows and land use in Austria 1950-2000: using the MEFA framework to monitor society-nature interaction for sustainability. Land Use Policy 21(3):215-230

Krausmann F, Erb KH et al (2008) Global patterns of socioeconomic biomass flows in the year 2000: a comprehensive assessment of supply, consumption and constraints. Ecol Econ 65:471
Krausmann F, Haberl H et al (2009a) What determines geographical patterns of the global human appropriation of net primary production? J Land Use Sci 4:15-33

Krausmann F, Gingrich S et al (2009b) Growth in global materials use, GDP and population during the 20th century. Ecol Econ 68(10):2696-2705

Lahiff E, Cousins B (2005) Smallholder agriculture and land reform in South Africa. IDS Bull 36(2):127-131

Laing MV (1994) Drought monitoring and advisory services in South Africa. Drought network news (1994-2001), National Drought Mitigation Center-University of Nebraska, Lincoln

Lauk C, Erb K-H (2009) Biomass consumed in anthropogenic vegetation fires: Global patterns and processes. Ecol Econ 9

Levy PI (1999) Sanctions on South Africa: what did they do? Am Econ Rev 89(2):415

Lindeman RL (1942) The trophic-dynamic aspect of ecology. Ecology 23:399-417

Liu J, Dietz T et al (2007) Complexity of coupled human and natural systems. Science 317(5844):1513-1516

Liverman DM, Cuesta RMR (2008) Human interactions with the Earth system: people and pixels revisited. Earth Surf Process Landf 33(9):1458-1471

Lundahl M (1984) Economic Effects of a trade and investment Boycott against South Africa. 86(1): 68-83. http://www.jstor. org/stable/3439404. Accessed 13 Oct 2010

Martinez-Alier J (1998) Ecological economics as human ecology. Fundación César Manrique, Madrid

Martinez-Alier J (1999) The socio-ecological embeddedness of economic activity: the emergence of a transdisciplinary field. In: Becker E, Jahn T (eds) Sustainability and the social sciences. Zed Books, London, pp 112-139

Michie J, Padayachee V (1998) Three years after apartheid: growth, employment and redistribution? Camb J Econ 22(5):623-636

Millennium Ecosystem Assessment (2005) Ecosystems and human well-being - our human planet. Summary for decision makers. Washington

Musel A (2009) Human appropriation of net primary production in the United Kingdom, 1800-2000: changes in society's impact on ecological energy flows during the agrarian-industrial transition. Ecol Econ 69(2):270-281

Ndlovu SM (1998) The Soweto uprisings: counter-memories of June 1976. Ravan Press, Randburg

Oerke EC, Dehne HW et al (1994) Crop production and crop protection: estimated losses in major food and cash crops. Elsevier, Amsterdam

Oldeman LR (1988) Guidelines for general assessment of the status of human-induced soil degradation. ISRIC, Wageningen

Ostrom E (2007) A diagnostic approach for going beyond panaceas. Proc Natl Acad Sci 104(39):15181-15187

Ostrom E, Janssen MA et al (2007) Going beyond panaceas. Proc Natl Acad Sci 104(39):15176-15178

Palmer AR, Ainslie A (2007) Using rain-use efficiency to explore livestock production trends in rangelands in the Transkei, South Africa. Afr J Range Forage Sci 24(1):43-49

Rindfuss RR, Walsh SJ et al (2004) Developing a science of land change: challenges and methodological issues. Proc Natl Acad Sci USA 101(39):13976-13981

Rouault M, Richard Y (2005) Intensity and spatial extent of droughts in southern Africa. Geophys Res Lett 32(15):L15702

Rouget M, Richardson DM, Cowling RM, Lloyd JW, Lomard AT (2003) Current patterns of habitat transformation and future threats to biodiversity in the terrestrial ecosystems of the Cape Floristic Region, South Africa. Biol Conserv 112(1-2):63-85

Scholes RJ, Biggs R (2005) A biodiversity intactness index. Nature 434(7029):45-49 
Schwarzlmüller E (2009) Human appropriation of aboveground net primary production in Spain, 1955-2003: an empirical analysis of the industrialization of land use. Ecol Econ 69(2):282-291

Simbi T, Aliber M (2000) Agricultural employment crisis in South Africa

Sitch S, Smith B et al (2003) Evaluation of ecosystem dynamics, plant geography and terrestrial carbon cycling in the LPJ dynamic global vegetation model. Glob Change Biol 9:161

Smil V (2005) Energy at the crossroads: global perspectives and uncertainties. The MIT Press, Massachusetts Institute of Technology

Sparrow GN, Ortmann GF et al (2008) Determinants of the demand for regular farm labour in South Africa, 1960-2002. Agrekon 47(1):52-75

Turner BL, Lambin EF et al (2007) The emergence of land change science for global environmental change and sustainability. Proc Natl Acad Sci 104(52):20666-20671

Tüxen R (1956) Die heutige potentielle natürliche Vegetation als Gegenstand der Vegetationskartierung. Angewandte Pflanzensoziologie 13:5-42

VanJaarsveld AS, Biggs R, Scholes RJ, Bohensky E, Reyers B, Lyman T, Musvoto C, Fabricius C (2005) Measuring conditions and trends of ecosystem services at multiple scale: the Southern African Millennium Ecosystem Assessment (SAfMA) experience. Phil Trans R Soc B 360:425-441
Verstraete MM, Scholes RJ et al (2009) Climate and desertification: looking at an old problem through new lenses. Front Ecol Environ 7(8):421-428

Vitousek PM (1997) Human domination of Earth's ecosystems. Science 277(5325):494-499

Vitousek PM, Ehrlich PR et al (1986) Human appropriation of the products of photosynthesis. Bioscience $36: 363$

Von Maltitz G, Scholes RJ (1995) The burning of fuelwood in South Africa: when is it sustainable? Environ Monit Assess 38:243-251

Wessels KJ, Prince SD et al (2004) Assessing the effects of humaninduced land degradation in the former homelands of northern South Africa with a $1 \mathrm{~km}$ AVHRR NDVI time-series. Remote Sens Environ 91:47

Williams A, Shackleton CM (2002) Fuelwood use in South Africa: where to in the 21 st century? S Afr For J 1-8

World Bank (2010) World development indicators, University of Manchester, ESDS International

Wright DH (1990) Human impacts on energy flow through natural ecosystems, and implications for species endangerment. Ambio 19(4):189-194

Zika M, Erb KH (2009) The global loss of net primary production resulting from human-induced soil degradation in drylands. Ecol Econ 69:310 